\title{
Vitamin D-related Nutrigenetics and Cognitive Decline in an Elderly Population
}

\author{
Charlotte Martin ${ }^{1}$, Zoe Yates $^{2}$, Martin Veysey ${ }^{3,4}$, Katrina King $^{4}$, Suzanne Niblett ${ }^{4}$ and Mark Lucock ${ }^{*}$ \\ ${ }^{1}$ University of Newcastle, Faculty of Science \& IT, School of Environmental \& Life Sciences, Ourimbah, New South Wales, Australia; \\ ${ }^{2}$ University of Newcastle, Faculty of Health, School of Biomedical Sciences \& Pharmacy, Ourimbah, New South Wales, Australia; \\ ${ }^{3}$ Teaching \& Research Unit, Central Coast Local Health District, Gosford, New South Wales, Australia; \\ ${ }^{4}$ University of Newcastle, Faculty of Health and Medicine, School of Medicine and Public Health, Callaghan,
}

New South Wales, Australia

\begin{abstract}
Background and objective: Vitamin $D$ has been linked to brain function. To date, there have been limited studies investigating vitamin $\mathrm{D}$ receptor (VDR) genetic polymorphisms and cognition. The objective of this study was, therefore, to examine whether any relationships exist between VDR polymorphisms and cognitive decline in an elderly population.
\end{abstract}

Methods: Six hundred and fifty participants aged $\geq 65$ years were recruited from the Central Coast, New South Wales, Australia, and were genotyped for 8 VDR polymorphisms (VDR-Apal, VDR-Bsml, VDR-Taql, VDR-Fokl, VDRTru91, VDR-Cdx2, VDR-A1012G, and VDR-NlallI). Gene variants were identified using polymerase chain reaction, followed by restriction fragment length polymorphism analysis and gel electrophoresis. Cognitive decline was measured using the mini-mental state examination (MMSE), while a self-administered food frequency questionnaire was used to estimate participants' dietary intake of vitamin D.

Results: Odds ratio (OR) analysis found that VDR-Bsml and VDR-Taql polymorphic alleles were both associated with increased risk of cognitive decline ( $O R=1.55$ and $O R=1.49$, respectively). VDR-Taql was also found to be significantly associated with MMSE score, following adjustment for age and sex $(p=0.0005)$. Examination of the distribution of VDR-Taql genotypes showed that a greater proportion of participants with the homozygous recessive $t t$ genotype had some degree of cognitive decline (24\%). As might be predicted, a significant association was also observed between age and MMSE score $(p=0.015)$. When examined by sex, a significant relationship was found between age and MMSE for females $(p \leq 0.0001)$ but no relationship was observed in males. Dietary intake of vitamin D did not influence MMSE outcomes in this cohort.

Conclusions: The VDR-Bsml and VDR-Taql genetic polymorphisms are associated with cognitive decline in an elderly population.

Keywords: Vitamin D; Cognition; Aging.

Abbreviations: AD, Alzheimer's disease; CI, confidence interval; FFQ, food frequency questionnaire; MCI, mild cognitive impairment; MMSE, mini mental state examination; OR, odds ratio; PD, Parkinson's disease; PCR, polymerase chain reaction; RFLP, restriction fragment length polymorphism; RHLS, Retirement Health and Lifestyle Study; SNP, single nucleotide polymorphism; UVR, ultraviolet radiation; VDR, vitamin D receptor.

Received: March 27, 2017; Revised: June 21, 2017; Accepted: July 19, 2017

${ }^{*}$ Correspondence to: Mark Lucock, School of Environmental \& Life Sciences, University of Newcastle, P.O. Box 127, Brush Rd, Ourimbah, NSW 2258, Australia. Tel: +61 43484109, Fax: +61 24348 4145, E-mail: mark.lucock@newcastle.edu.au

How to cite this article: Martin C, Yates Z, Veysey M, King K, Niblett S, Lucock M. Vitamin D-related Nutrigenetics and Cognitive Decline in an Elderly Population. Exploratory Research and Hypothesis in Medicine 2017;2(4):131-138. doi: 10.14218/ ERHM.2017.00006
Introduction

Vitamin D receptor (VDR) is a member of the nuclear receptor superfamily and participates in a number of diverse biological actions, due to its distribution in almost all organs and tissues. This expression pattern includes the brain, where VDR expression has been detected in the hypothalamus, hippocampus, cortex and subcortical regions, ${ }^{1,2}$ which are essential for cognition. The active form of vitamin $\mathrm{D}, 1,25(\mathrm{OH})_{2} \mathrm{D}_{3}$, plays an important role in neuronal differentiation and maturation by controlling the synthesis of neurotrophic agents, ${ }^{1,3}$ and also by regulating the expression of numerous genes involved in neurotransmitter synthesis, predomi- 


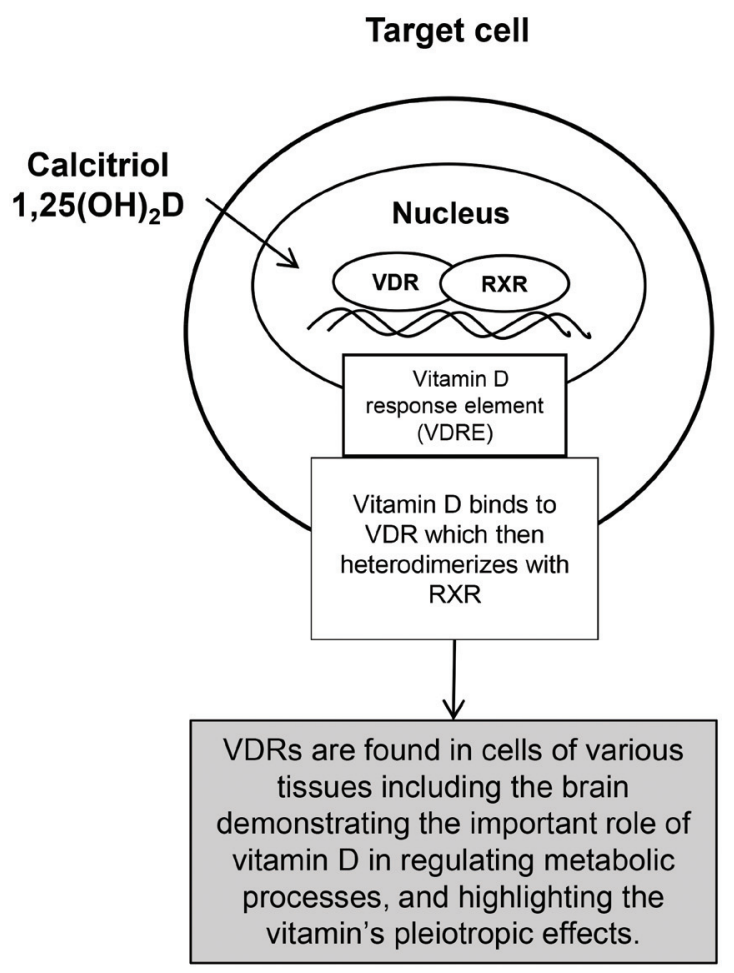

Fig. 1. Interaction of calcitriol in the target cell in regulating metabolic processes such as brain health.

nantly in the hippocampus (Fig. 1).,5

The VDR is well known for modulating the transcription of genes encoding proteins that execute the "classic" genomic functions of vitamin D for skeletal and mineral homeostasis. However, it also regulates the expression of several genes that mediate "nonclassical" actions in non-calcemic tissues. Many of these "nonclassical" actions are associated with decreased risk for disorders associated with ageing, including those linked to the nervous system. ${ }^{6,7}$ The elderly are particularly at risk for a number of degenerative disorders related to low serum calcidiol $\left(25(\mathrm{OH}) \mathrm{D}_{3}\right)$ levels. This is due to a decrease in ultraviolet radiation (UVR) exposure as a consequence of changes in lifestyle, particularly a decline in outdoor activity. ${ }^{8}$

Diet can also become less varied with age, resulting in low intake of vitamin D content. ${ }^{9}$ Most significant, however, is a decrease in the ability to synthesise cutaneous vitamin D after UVR exposure-a result of atrophic changes in the skin and a reduced level of the vitamin D precursor, 7-dehydrocholesterol. ${ }^{10}$ Investigation of the impact of vitamin D deficiency on the ageing brain is critical, with evidence linking low vitamin D status with poorer outcomes on one or more cognitive function tests, ${ }^{11,12}$ or a higher frequency of dementia, ${ }^{13}$ mood disorders, ${ }^{14}$ cognitive decline and Alzheimer's disease (AD). ${ }^{15-17}$

The VDR gene is located on chromosome 12 (12q13.11) and contains several known polymorphisms. VDR-ApaI (G>T substitution) and VDR-BsmI (A $>$ G substitution) are restriction fragment length polymorphisms (RFLPs) located at the intron between exon $8-9$, and are considered to be silent single nucleotide polymorphisms (SNPs) as they do not change the amino acid sequence of the encoded VDR protein. ${ }^{15,16}$ They may, however, alter gene expression through regulation of messenger RNA.16,17 VDR-TaqI ( $\mathrm{T}>\mathrm{C}$ substitution) is a RFLP in exon 9, while the VDR-FokI polymorphism ( $\mathrm{T}>\mathrm{C}$ substitution) is situated at the start of the codon in exon 2 of the VDR gene. ${ }^{18}$ The VDR-Tru 91 (G>A substitution) located within the intron 8 region has been studied to a lesser extent. ${ }^{16,19}$ Other polymorphisms in the $1 \mathrm{~A}$ promoter region, including VDR- $C d x 2$, VDR-A1012G and VDR-G1520C, have also recently been reported. ${ }^{20}$

The objective of this study was to examine the relationship between eight vitamin D-related genetic polymorphisms and cognitive decline in an elderly cohort. Furthermore, dietary intake of vitamin $\mathrm{D}$ and other related markers were analysed to determine their influence on cognition.

\section{Methods}

\section{Study design}

A total of 650 participants (287 males and 363 females, aged 65-95 years) living independently in either a retirement village or within the community on the Central Coast, New South Wales were assessed for the prevalence of eight VDR genetic polymorphisms, dietary intake of vitamin $\mathrm{D}$, and cognitive ability using the mini-mental state examination (MMSE). Following screening, all dementia participants were excluded from the study.

Informed consent was obtained from all participants prior to study participation. This cross-sectional study was approved by the University of Newcastle Human Research Ethics Committee (H-2008-0431), and the Occupational Health and Safety Committee (28.2009). The study was fully compliant with the Helsinki Declaration. The data used in the present study formed part of a larger Retirement Health and Lifestyle Study (RHLS) funded by an Australian Research Council Linkage Project

Table 1. Summary of the PCR reagents and thermal cycling conditions for each VDR polymorphism

\begin{tabular}{|c|c|c|c|c|c|}
\hline Gene variant & $\begin{array}{l}\text { GoTaq }{ }^{\circledR} \text { Green } \\
\text { Master Mix, } \mu \mathrm{L}\end{array}$ & $\begin{array}{l}\text { Primer in } \\
5 \text { pmol, } \mu \mathrm{L}\end{array}$ & DNA, $\mu \mathrm{L}$ & $\mathrm{H}_{2} \mathrm{O}, \mu \mathrm{L}$ & Thermal cycling conditions \\
\hline VDR-A1012G & 10 & 4 & 2 & 4 & $\begin{array}{l}95^{\circ} \mathrm{C} \times 2 \mathrm{~min} ; 35 \times\left[95^{\circ} \mathrm{C} \times 30 \mathrm{sec} ; 58^{\circ} \mathrm{C} \times 30\right. \\
\left.\mathrm{sec} ; 72^{\circ} \mathrm{C} \times 30 \mathrm{sec}\right] ; 72^{\circ} \mathrm{C} \times 7 \mathrm{~min} ; \text { hold at } 15^{\circ} \mathrm{C}\end{array}$ \\
\hline $\begin{array}{l}\text { VDR-Taql, VDR-Apal, VDR-Bsml, } \\
\text { VDR-Fokl, VDR-Tru91*** }\end{array}$ & 10 & 4 & 2 & 4 & $\begin{array}{l}95^{\circ} \mathrm{C} \times 3 \mathrm{~min} ; 35 \times\left[95^{\circ} \mathrm{C} \times 30 \mathrm{sec} ; 61^{\circ} \mathrm{C} \times 30\right. \\
\left.\mathrm{sec} ; 72^{\circ} \mathrm{C} \times 30 \mathrm{sec}\right] ; 72^{\circ} \mathrm{C} \times 7 \mathrm{~min} ; \text { hold at } 15^{\circ} \mathrm{C}\end{array}$ \\
\hline $\begin{array}{l}\text { VDR-Cdx2 G* } \\
\text { VDR-Cdx2 A* }\end{array}$ & $\begin{array}{l}10 \\
10\end{array}$ & $\begin{array}{l}2.4 \\
1.6\end{array}$ & $\begin{array}{l}2 \\
2\end{array}$ & $\begin{array}{l}4 \\
4\end{array}$ & $\begin{array}{l}95^{\circ} \mathrm{C} \times 3 \mathrm{~min} ; 35 \times\left[95^{\circ} \mathrm{C} \times 30 \mathrm{sec} ; 56^{\circ} \mathrm{C} \times 45\right. \\
\left.\mathrm{sec} ; 72^{\circ} \mathrm{C} \times 30 \mathrm{sec}\right] ; 72^{\circ} \mathrm{C} \times 7 \mathrm{~min} ; \text { hold at } 15^{\circ} \mathrm{C}\end{array}$ \\
\hline VDR-NIaIII & 10 & 4 & 2 & 4 & $\begin{array}{l}95^{\circ} \mathrm{C} \times 2 \mathrm{~min} ; 35 \times\left[95^{\circ} \mathrm{C} \times 30 \mathrm{sec} ; 58^{\circ} \mathrm{C} \times 30\right. \\
\left.\mathrm{sec} ; 72^{\circ} \mathrm{C} \times 30 \mathrm{sec}\right] ; 72^{\circ} \mathrm{C} \times 7 \mathrm{~min} ; \text { hold at } 15^{\circ} \mathrm{C}\end{array}$ \\
\hline
\end{tabular}


Table 2. Primer sequences for each VDR polymorphism

\begin{tabular}{|c|c|c|c|c|}
\hline Gene variant & Forward primer, $5^{\prime} \rightarrow 3^{\prime}$ & Reverse primer, $5^{\prime} \rightarrow 3^{\prime}$ & $\begin{array}{l}\text { Fragment } \\
\text { length, bp }\end{array}$ & Ref \\
\hline VDR-A1012G & СCT CCT CTG TAA GAG GCG AAT AGC GAT & GGA CAG GTG AAA AAG ATG GGG TTC & 177 & [22] \\
\hline VDR-TaqI, VDR-Apal*** & ACG TCT GCA GTG TGT TGG AC & TCA CCG GTC AGC AGT CAT AG & 211 & [23] \\
\hline VDR-Bsml & CAG TTC ACG CAA GAG CAG AG & ACC TGA AGG GAG ACG TAG CA & 236 & {$[24]$} \\
\hline $\begin{array}{l}\text { VDR-Cd } \times 2 \mathrm{G}^{*} \\
\text { VDR-Cdx2 A* }\end{array}$ & $\begin{array}{l}\text { AGG ATA GAG AAAA TAA TAG AAA ACA TT } \\
\text { TCC TGA GTA AAC TAG GTC ACA A }\end{array}$ & $\begin{array}{l}\text { AAC CCA TAA TAA GAA ATA AGT TTT TAC } \\
\text { ACG TTA AGT TCA GAA AGA TTA ATT C }\end{array}$ & 297 & [22] \\
\hline VDR-Fokl & TGC AGC CTT CAC AGG TCA TA & GGC CTG CTT GCT GTT CTT AC & 157 & {$[25]$} \\
\hline VDR-NIaIII & TGC AGA GAA TGT CCC AAG GT & GTC CTG CCA GTC TGA TGG AT & 236 & [26] \\
\hline VDR-Tru91 & GCA GGG TAC AAA ACT TTG GAG & CCT CAT CAC CGA CAT CAT GTC & 177 & [19] \\
\hline
\end{tabular}

Grant.

\section{DNA analysis}

VDR gene variants were examined using polymerase chain reaction (PCR) to amplify blood DNA, followed by RFLP analysis and gel electrophoresis. Initially, a QIAamp DNA blood mini-kit was used to extract DNA from whole blood using the QIAamp blood and body fluid spin protocol. ${ }^{21}$ The optimal PCR reaction mixture and temperature varied for each polymorphism examined. Table 1 provides the thermal cycling conditions for each VDR polymor- phism, whilst Table $2^{19,22-26}$ gives the primer sequence details for VDR-ApaI, VDR-BsmI, VDR-TaqI, VDR-FokI, VDR-Tru91, VDR-Cdx2, VDR-A1012G and VDR-NIaIII. RFLP was performed following PCR amplification, as described in Table 3. VDR-Cdx2 requires a nested primer allele-specific strategy for genotype scoring, eliminating the need for enzyme digestion. Examples of each genotype for each VDR polymorphism can be seen in Figure 2.

\section{MMSE}

The MMSE is a screening tool used to assess dementia, and fo-

Table 3. Summary of the restriction enzyme digestion reactions and electrophoresis conditions for each VDR polymorphism

\begin{tabular}{|c|c|c|c|c|c|c|c|}
\hline Gene variant & $\begin{array}{l}\text { Restriction } \\
\text { endonuclease }\end{array}$ & $\begin{array}{l}\text { PCR } \\
\text { product, } \\
\mu \mathrm{L}\end{array}$ & Digestion buffer & Other & $\begin{array}{l}\text { Incubation length } \\
\text { \& temperature }\end{array}$ & $\begin{array}{l}\text { Gel conditions } \\
\text { - Agarose } \%\end{array}$ & $\begin{array}{l}\text { Fragment of } \\
\text { gel, bp }\end{array}$ \\
\hline VDR-A1012G & $20 U$ EcoRV & 5 & 10x Buffer $4(1 \mu \mathrm{L})$ & $3.8 \mu \mathrm{L} \mathrm{H} \mathrm{H}_{2} \mathrm{O}$ & $6 \mathrm{hr} @ 37^{\circ} \mathrm{C}$ & 3 & $\begin{array}{l}\text { AA: } 150,27 \\
\text { AG: } 177,150,27 \\
\text { GG: } 177\end{array}$ \\
\hline VDR-TaqI & $20 U \mathrm{Taql}$ & 5 & 10x Buffer $4(1 \mu L)$ & $\begin{array}{l}1 \mu \mathrm{LBSA} \\
2.8 \mu \mathrm{L} \mathrm{H} \mathrm{H}_{2}\end{array}$ & $3 \mathrm{hr} 20 \mathrm{~min} @ 65^{\circ} \mathrm{C}$ & 3 & $\begin{array}{l}\text { TT: } 211 \\
\text { Tt: } 211,172,39 \\
\text { tt: } 172,39\end{array}$ \\
\hline VDR-Apal & $50 \mathrm{U} A p a \mathrm{l}$ & 5 & 10x Buffer $4(1 \mu \mathrm{L})$ & $\begin{array}{l}1 \mu \mathrm{LBSA} \\
2.9 \mu \mathrm{L} \mathrm{H} \mathrm{H}_{2} \mathrm{O}\end{array}$ & $3 \mathrm{hr} @ 25^{\circ} \mathrm{C}$ & 3 & $\begin{array}{l}\text { AA: } 211 \\
\text { Aa: } 211,121,90 \\
\text { aa: } 121,90\end{array}$ \\
\hline VDR-Bsml & $10 \cup \mathrm{Bsml}$ & 5 & 10x Buffer $4(1 \mu \mathrm{L})$ & $3.5 \mu \mathrm{L} \mathrm{H} \mathrm{H}_{2} \mathrm{O}$ & $3 \mathrm{hr} 20 \min @ 65^{\circ} \mathrm{C}$ & 3 & $\begin{array}{l}\text { BB: } 236 \\
\text { Bb: } 236,197,39 \\
\text { bb: } 197,39\end{array}$ \\
\hline $\begin{array}{l}\text { VDR-Cdx2 G* } \\
\text { VDR-Cdx2 A* }\end{array}$ & Not applicable & & & & & 3 & $\begin{array}{l}\text { GG: } 297,110 \\
\text { AG: } 297,235,110 \\
\text { AA: } 297,235\end{array}$ \\
\hline VDR-Fokl & $4 \mathrm{U}$ Fokl & 5 & 10x Buffer $4(1 \mu \mathrm{L})$ & $3 \mu \mathrm{L} \mathrm{H} \mathrm{H}_{2} \mathrm{O}$ & $3.5 \mathrm{hr} @ 37^{\circ} \mathrm{C}$ & 3 & $\begin{array}{l}\text { FF: } 157 \\
\text { Ff: } 157,121,36 \\
\text { ff: } 121,36\end{array}$ \\
\hline VDR-NIallI & $10 \mathrm{U}$ NlallI & 5 & 10x Buffer $4(1 \mu \mathrm{L})$ & $2.5 \mu \mathrm{L} \mathrm{H} \mathrm{H}_{2} \mathrm{O}$ & $6 \mathrm{hr} @ 37^{\circ} \mathrm{C}$ & 3 & $\begin{array}{l}\text { GG: } 236 \\
\text { GC: } 236,197,39 \\
\text { CC: } 197,39\end{array}$ \\
\hline VDR-Tru91 & $4 \mathrm{U}$ Msel & 5 & 10x Buffer $4(1 \mu \mathrm{L})$ & $3 \mu \mathrm{L} \mathrm{H} \mathrm{H}_{2} \mathrm{O}$ & $3.5 \mathrm{hr} @ 37^{\circ} \mathrm{C}$ & 3 & $\begin{array}{l}\text { UU: } 177 \\
\text { Uu: } 177,91,86 \\
\text { uu: } 91,86\end{array}$ \\
\hline
\end{tabular}


A VDR-Apal

M AA Aa Aa AA aa Aa Aa Aa aa AA Aa

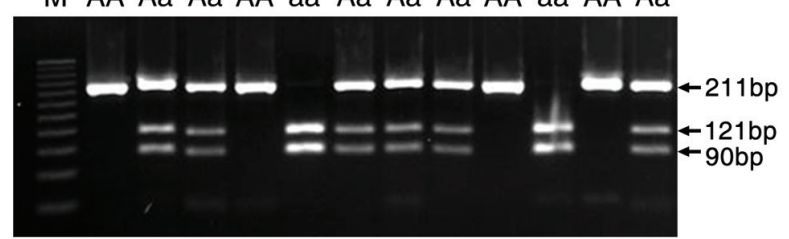

C

M AA AG AA GG AG AG AA GG AA AG AG AA

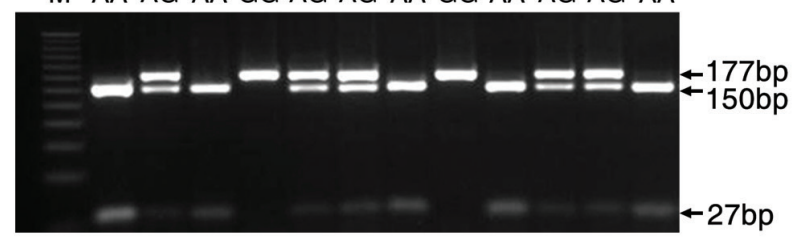

E

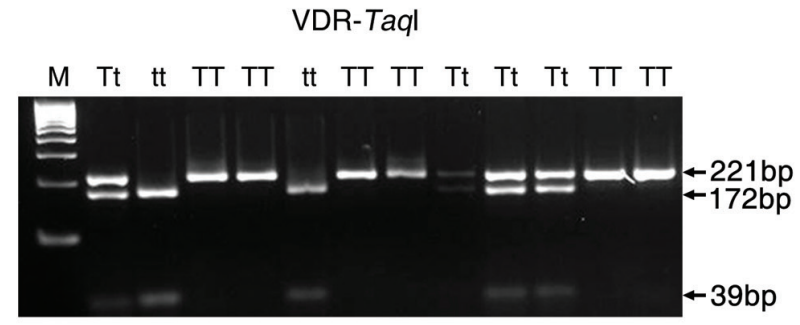

G

VDR-Cdx2

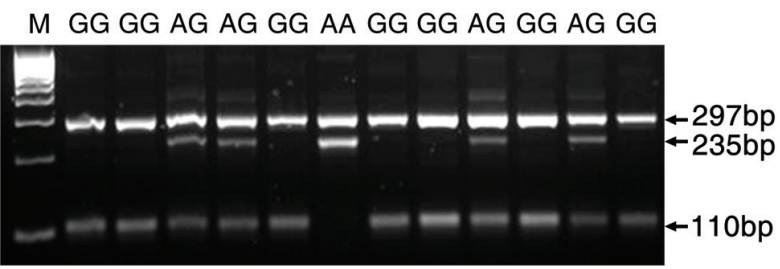

B

VDR-Bsml

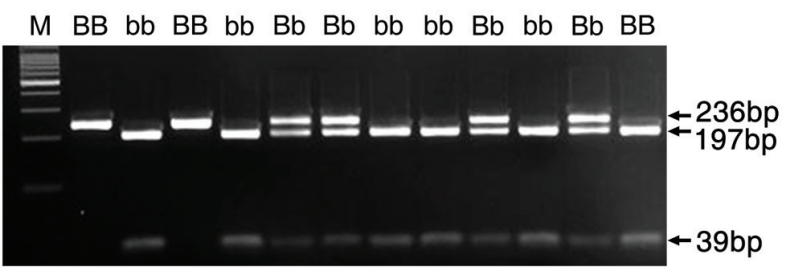

D

VDR-Fokl

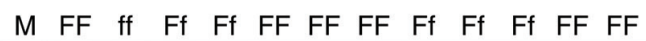

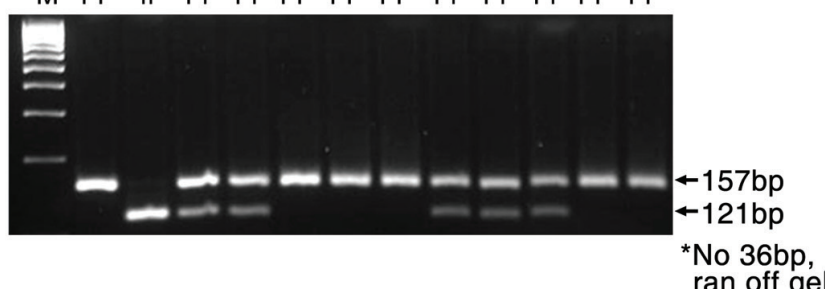

F

VDR-Tru91

ran off gel

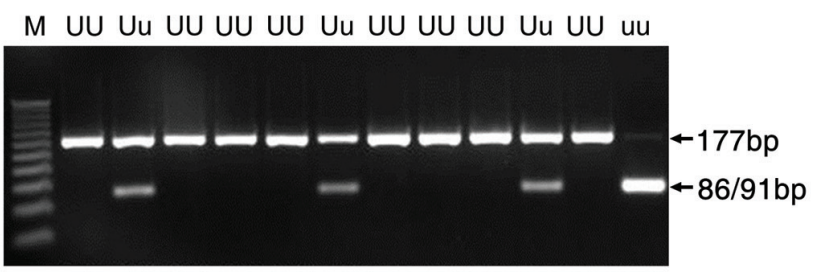

Fig. 2. Examples of each genotype (wild type, heterozygote, homozygous recessive) for the VDR polymorphisms examined in this study. A: VDR-Apal; B: VDR-Bsml; C: VDR-A1012G; D: VDR-Fokl; E: VDR-Taql; F: VDR-Tru91; G: VDR-Cdx2. See Table 3 for further information on banding patterns.

cuses solely on the cognitive characteristics of mental functions, excluding questions involving mood, abnormal mental experiences and the form of thinking. ${ }^{27}$ The MMSE is comprised of 11 questions, covering: orientation to time; orientation to place; registration of three words; language; and visual construction. A score of more than 25 (out of 30 ) is classified as normal, whilst a score of 25 or less is indicative of some degree of cognitive decline. ${ }^{28}$

\section{Food frequency questionnaire (FFQ)}

Participants completed a self-administered FFQ, enabling an estimation of daily vitamin D intake. The FFQ was comprised of 38 questions relating to diet, covering 205 food items and all food groups. Participants also provided a full list of supplements they were taking, enabling an estimation of total dietary intake of vitamin D. Each FFQ was analysed in FoodWorks ${ }^{\mathrm{TM}}$ (version 6.0.2562) nutritional analysis software program (Xyris Software, Brisbane,
QLD, Australia), providing a breakdown of vitamin D intake measured as an average per day. This software package is comprised of a number of different food databases, covering the majority of foods consumed by Australians. These include: Abbott products, Ausfoods (brand food) 2007, and Aus Nut (all foods) 2006.

\section{Statistics}

Statistical analysis was conducted using Microsoft Excel 2010 and JMP for Windows (version 11; SAS Institute Inc., Cary, NC, US). Age quartiles, sex and dietary vitamin $\mathrm{D}$ data distributions were examined, with mean, standard deviation (SD), median and interquartile range (IQR) reported as appropriate. Participants were stratified by sex and by cognitive decline based on the cut-off score of the MMSE $(\leq 25=$ cognitive decline; $>25=$ no cognitive decline). Genotype prevalence (\%), allele number (frequency) and carriage of polymorphic allele $(\%)$ were ascertained and tabulated 
Table 4. Descriptive data for all subjects and for those participants with and without cognitive decline, based on MMSE ( $\leq 25=$ cognitive decline; $>\mathbf{2 5}=$ no cognitive decline)

\begin{tabular}{llll}
\hline & All subjects & Cognitive decline & No cognitive decline \\
\hline $\begin{array}{l}\text { Number of participants } \\
\text { Sex }\end{array}$ & 650 & $73(11 \%)$ & $575(89 \%)$ \\
$\quad$ & & \\
$\quad$ Male & 287 & $33(12 \%)$ & $253(88 \%)$ \\
$\quad$ Female & 363 & $40(11 \%)$ & $322(89 \%)$ \\
Age, $\bar{x} \pm$ SD; median (IQR) & $77.8 \pm 7.0 ;$ & $79.6 \pm 7.6 ;$ & $77.5 \pm 6.9 ;$ \\
& $78(72-83) ;$ & $80(74-86) ;$ & $78(72-83) ;$ \\
Total dietary vitamin D in $\mu \mathrm{g} / \mathrm{d}$, & $7.76 \pm 11.54 ;$ & $8.41 \pm 10.78 ;$ & $7.65 \pm 11.61 ;$ \\
$\bar{x} \pm$ SD; median (IQR) & $2.65(1.77-7.93)$ & $2.87(1.9-12.24)$ & $2.65(1.75-7.41)$ \\
\hline
\end{tabular}

according to cognitive decline. The degree and significance of an allele as a risk factor for a given biochemical/clinical phenotype was ascertained using an odds ratio (OR) and associated $95 \%$ confidence interval (CI)

The cognitive decline phenotype was defined as nominal data, and stepwise regression was used to create the best model, for subsequent nominal logistic regression analysis. Stepwise regression was performed in a mixed direction with significant probability $[0.250]$ for a parameter to be considered as a forward step and entered into the model or considered as a backward step and removed from the model. Mallow's Cp criterion was used for selecting the model where $\mathrm{Cp}$ first approaches $p$ variables. $R^{2}$ is reported and is the proportion of the variation in the response that can be attributed to terms in the model as opposed to random error. While an initial alpha level of 0.05 was set, Bonferroni corrections for multiple comparisons were also applied. Data is reported after adjusting for age and sex in analyses where stepwise regression modelling was used.

\section{Results}

Descriptive data for all subjects with and without cognitive decline is provided in Table 4, while the distribution of cognitive decline by age quartiles for each sex is given in Table 5. Seventy-three participants $(11 \%)$ were found to exhibit some degree of cognitive decline based on their MMSE score. When examined by age quartiles, the proportion of participants with cognitive decline was highest in males in the 65-72 year-old group $(15.2 \%)$ and the $73-80$ year-old group (11.3\%), and highest in females in the 81-88 year-old group (15.9\%) and 89-95 year-old groups (28.6\%) (Table $5)$. Total vitamin $D$ intake (diet + supplements) was similar for participants with or without cognitive decline.

Table 6 presents the genetic distribution of each vitamin D-related polymorphism for the cognitive decline phenotype, and gives the genotype prevalence (\%), allele number (frequency) and carriage of polymorphic allele (\%). An OR and associated 95\% CI were calculated to assess the degree of significance of risk for each of the vitamin D-related gene polymorphisms in relation to cognitive decline. Table 6 also shows that the VDR-BsmI and VDR-TaqI polymorphic alleles were both associated with an increased risk of cognitive decline $(\mathrm{OR}=1.55,95 \% \mathrm{CI}: 1.08-2.22$ and $\mathrm{OR}=1.49$, 95\% CI: $1.04-2.14$, respectively).

Multivariate analyses of all vitamin D-related genetic polymorphisms using stepwise regression showed a significant relationship between VDR-TaqI and MMSE $\left(p=0.0014 ; R^{2}=0.0292\right)$. When adjusted for age and sex, the relationship between VDR-TaqI and MMSE remained significant ( $p=0.0004 ; R^{2}=0.0473$ ). Both results upheld their significance following a Bonferroni correction. To further examine the significant relationship between VDR-TaqI and MMSE, the percentage of participants with cognitive decline for each genotype was calculated. Figure 3 shows that the highest percentage of participants with some degree of cognitive decline was amongst those with the homozygous recessive $t$ genotype (24\%).

Nominal logistic regression analysis was used to examine the relationships between other variables and MMSE score, independent of genetic influence. Results showed a significant inverse association between age and MMSE score $\left(p=0.0145 ; R^{2}=0.0131\right.$; slope estimate $=-0.0180$ ), and when examined by sex, a significant relationship was shown between age and MMSE for females $\left(p \leq 0.0001 ; R^{2}=0.0865\right.$; slope estimate $\left.=-0.1160\right)$ but not males

\section{Discussion}

The present study examined the relationship between VDR polymorphisms and cognition in 650 elderly participants using the MMSE to assess their degree of cognitive decline. An OR analysis showed that both the VDR-BsmI and VDR-TaqI polymorphic alleles increased the risk of cognitive decline and that the VDRTaqI genetic polymorphism was also significantly associated with MMSE score. The percentage of participants with some degree of cognitive decline was highest amongst those with the VDR-TaqI homozygous recessive tt genotype (24\%).

Vitamin D is important for brain and other physiological functions, and plays an important role in the biosynthesis of neuro-

Table 5. Distribution of cognitive decline by age quartiles for each sex, based on MMSE ( $\leq 25=$ cognitive decline; $>25=$ no cognitive decline) with percentage of participants with and without cognitive decline for each age quartile

\begin{tabular}{llllll}
\hline & & $\mathbf{6 5 - 7 2} \mathbf{~ y r}$ & $\mathbf{7 3 - 8 0} \mathbf{~ r r}$ & $\mathbf{8 1 - 8 8 ~} \mathbf{~ r r}$ & $\mathbf{8 9 - 9 5} \mathbf{~ r r}$ \\
\hline \multirow{2}{*}{ Males } & Cognitive decline & $12(15 \%)$ & $12(11 \%)$ & $8(9 \%)$ & $1(6 \%)$ \\
& No cognitive decline & $67(85 \%)$ & $94(89 \%)$ & $77(91 \%)$ & $15(94 \%)$ \\
Females & Cognitive decline & $3(3 \%)$ & $12(9 \%)$ & $17(16 \%)$ & $8(29 \%)$ \\
& No cognitive decline & $85(97 \%)$ & $127(91 \%)$ & $90(84 \%)$ & $20(71 \%)$ \\
\hline
\end{tabular}


Table 6. Occurrence of cognitive decline phenotype, based on MMSE ( $\leq 25$ = cognitive decline; $>\mathbf{2 5}=$ no cognitive decline), for genotype prevalence, allele number and carriage of polymorphic allele for vitamin D-related genetic polymorphisms

\begin{tabular}{|c|c|c|c|c|c|c|c|c|c|}
\hline \multirow{2}{*}{$\begin{array}{l}\text { Polymor- } \\
\text { phism }\end{array}$} & \multirow{2}{*}{ Phenotype } & \multicolumn{3}{|c|}{$\begin{array}{c}\text { Genotype prevalence } \\
(\%)^{\mathrm{a}}\end{array}$} & \multicolumn{2}{|c|}{$\begin{array}{l}\text { Allele number } \\
\text { (frequency) }\end{array}$} & \multirow{2}{*}{$\begin{array}{l}\text { Carriage } \\
\text { of poly- } \\
\text { morphic, } \\
\text { allele \% }\end{array}$} & \multirow{2}{*}{$\begin{array}{l}\text { Odds } \\
\text { ratio }\end{array}$} & \multirow{2}{*}{$\begin{array}{l}\mathrm{Cl} \text { (Yates cor- } \\
\text { rected } \mathrm{p} \text { value) }\end{array}$} \\
\hline & & Wildtype & $\begin{array}{l}\text { Hete- } \\
\text { rozygous }\end{array}$ & $\begin{array}{l}\text { Reces- } \\
\text { sive }\end{array}$ & Wildtype & $\begin{array}{l}\text { Polymor- } \\
\text { phic }\end{array}$ & & & \\
\hline VDR-A1012G & $\begin{array}{l}\text { Cognitive decline } \\
\text { No cognitive decline }\end{array}$ & $\begin{array}{l}22(31) \\
185(33)\end{array}$ & $\begin{array}{l}40(56) \\
272(48)\end{array}$ & $\begin{array}{l}10(13) \\
108(19)\end{array}$ & $\begin{array}{l}84(0.58) \\
642(0.57)\end{array}$ & $\begin{array}{l}60(0.42) \\
488(0.43)\end{array}$ & $\begin{array}{l}69 \\
67\end{array}$ & & \\
\hline VDR-Apal & $\begin{array}{l}\text { Cognitive decline } \\
\text { No cognitive decline }\end{array}$ & $\begin{array}{l}14(19) \\
120(21)\end{array}$ & $\begin{array}{l}30(41) \\
298(53)\end{array}$ & $\begin{array}{l}29(40) \\
148(26)\end{array}$ & $\begin{array}{l}58(0.40) \\
538(0.48)\end{array}$ & $\begin{array}{l}88(0.60) \\
594(0.52)\end{array}$ & $\begin{array}{l}81 \\
79\end{array}$ & & \\
\hline VDR-Bsml & $\begin{array}{l}\text { Cognitive decline } \\
\text { No cognitive decline }\end{array}$ & $\begin{array}{l}22(31) \\
207(37)\end{array}$ & $\begin{array}{l}29(40) \\
277(49)\end{array}$ & $\begin{array}{l}21(29) \\
79(14)\end{array}$ & $\begin{array}{l}73(0.51) \\
691(0.61)\end{array}$ & $\begin{array}{l}71(0.49) \\
435(0.39)\end{array}$ & $\begin{array}{l}69 \\
63\end{array}$ & 1.55 & $1.075-2.220(0.0180)$ \\
\hline VDR-Cdx2 & $\begin{array}{l}\text { Cognitive decline } \\
\text { No cognitive decline }\end{array}$ & $\begin{array}{l}12(50) \\
87(50)\end{array}$ & $\begin{array}{l}11(46) \\
71(41)\end{array}$ & $\begin{array}{l}1(4) \\
15(9)\end{array}$ & $\begin{array}{l}35(0.73) \\
245(0.71)\end{array}$ & $\begin{array}{l}13(0.27) \\
101(0.29)\end{array}$ & $\begin{array}{l}50 \\
50\end{array}$ & & \\
\hline VDR-Fokl & $\begin{array}{l}\text { Cognitive decline } \\
\text { No cognitive decline }\end{array}$ & $\begin{array}{l}3(12) \\
29(17)\end{array}$ & $\begin{array}{l}10(40) \\
85(49)\end{array}$ & $\begin{array}{l}12(48) \\
61(34)\end{array}$ & $\begin{array}{l}16(0.32) \\
143(0.41)\end{array}$ & $\begin{array}{l}34(0.68) \\
207(0.59)\end{array}$ & $\begin{array}{l}88 \\
83\end{array}$ & & \\
\hline VDR-NlaIII & $\begin{array}{l}\text { Cognitive decline } \\
\text { No cognitive decline }\end{array}$ & $\begin{array}{l}10(40) \\
56(32)\end{array}$ & $\begin{array}{l}13(52) \\
87(50)\end{array}$ & $\begin{array}{l}2(8) \\
32(18)\end{array}$ & $\begin{array}{l}33(0.66) \\
199(0.57)\end{array}$ & $\begin{array}{l}17(0.34) \\
151(0.43)\end{array}$ & $\begin{array}{l}60 \\
68\end{array}$ & & \\
\hline VDR-TaqI & $\begin{array}{l}\text { Cognitive decline } \\
\text { No cognitive decline }\end{array}$ & $\begin{array}{l}25(34) \\
203(37)\end{array}$ & $\begin{array}{l}27(37) \\
280(51)\end{array}$ & $\begin{array}{l}21(29) \\
66(12)\end{array}$ & $\begin{array}{l}77(0.53) \\
686(0.62)\end{array}$ & $\begin{array}{l}69(0.47) \\
412(0.38)\end{array}$ & $\begin{array}{l}66 \\
63\end{array}$ & 1.49 & $1.039-2.142(0.0290)$ \\
\hline VDR-Tru91 & $\begin{array}{l}\text { Cognitive decline } \\
\text { No cognitive decline }\end{array}$ & $\begin{array}{l}59(81) \\
414(73)\end{array}$ & $\begin{array}{l}13(18) \\
138(24)\end{array}$ & $\begin{array}{l}1(1) \\
16(3)\end{array}$ & $\begin{array}{l}131(0.90) \\
966(0.85)\end{array}$ & $\begin{array}{l}15(0.10) \\
170(0.15)\end{array}$ & $\begin{array}{l}19 \\
27\end{array}$ & & \\
\hline
\end{tabular}

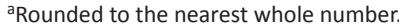

transmitters, ${ }^{4}$ neuroprotection, ${ }^{5}$ immunomodulation and detoxification. ${ }^{4}$ Consequently, some of these biological effects suggest that vitamin D may influence cognitive function and mood disorders. Evidence surrounding vitamin D and the human brain have revealed individuals are increasingly vulnerable to mood disorders during the winter months, ${ }^{29,30}$ and a vitamin D deficiency may contribute to seasonal affective disorder. Additionally, evidence has shown a link between low vitamin D status and mood disorders, accompanied with poor cognitive function. ${ }^{31}$ Balion et al. ${ }^{32}$ conducted a systematic review and meta-analysis to examine the association between vitamin $\mathrm{D}$, cognitive function and MMSE score;

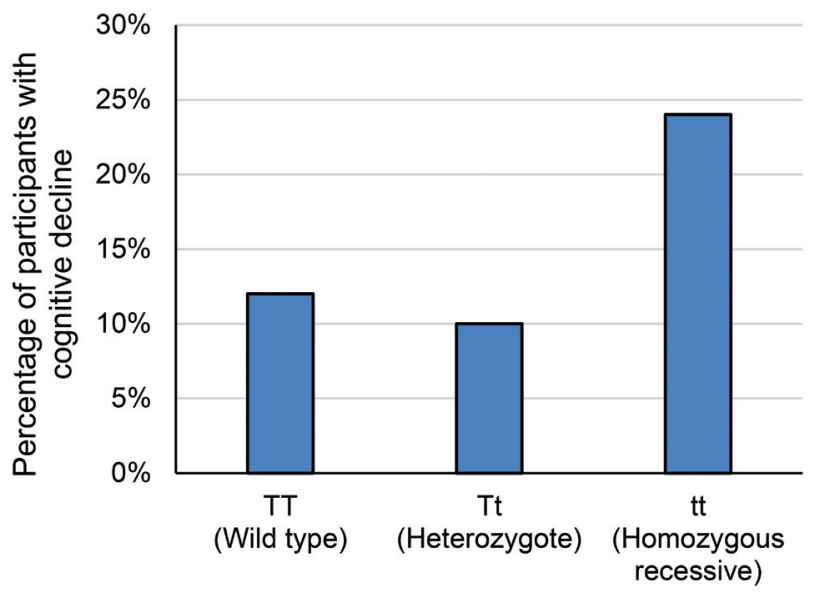

VDR-Taql genotypes

Fig. 3. Percentage of participants with each VDR-Taql gene variant (wild type $\mathrm{TT}$, heterozygote $\mathrm{Tt}$, homozygous recessive $\mathrm{tt}$ ) and cognitive decline, based on an MMSE score of $\leq 25$. overall, it was found that lower vitamin D concentrations were associated with poorer cognitive scores and higher $\mathrm{AD}$ risk. In the present study, no associations were found between dietary vitamin D intake and MMSE score.

Research surrounding VDR polymorphisms and cognition have mostly focused on $\mathrm{AD},{ }^{33,34}$ and to a lesser extent cognitive decline. ${ }^{35}$ In one study, a meta-analysis found associations between VDR polymorphisms and AD and Parkinson's disease (PD) susceptibility. ${ }^{36}$ Other findings include a significant association between the VDR-TaqI "T" allele and AD susceptibility (OR = $0.735,95 \%$ CI: $0.596-0.907),{ }^{36}$ while in a further study the VDRApaI A allele and AA genotype increased the risk of mild cognitive impairment $(\mathrm{MCI})(\mathrm{OR}=1.62,95 \% \mathrm{CI}: 1.13-2.31$ and $\mathrm{OR}=3.49$, 95\% CI: $1.570-7.740$, respectively). ${ }^{24}$ The results also showed that the variant $\mathrm{B}$ allele of VDR-BsmI increased the risk of $\mathrm{MCI}(\mathrm{OR}=$ 1.94, 95\% CI: 1.240-3.050). ${ }^{37}$

Najmi Varzaneh et al. ${ }^{38}$ found the VDR-FokI was significantly associated with cognitive function following assessment using the MMSE. Examination of cognitive function amongst FokI genotypes showed "FF" participants had a higher cognitive score compared with "ff" participants. ${ }^{38}$ Similar findings were shown for FokI in a recent longitudinal study by Gatto et al. ${ }^{39}$ This study examined VDR polymorphisms with PD using the MMSE, and found that for each additional copy of the FokI-A allele (also referred to as the " $\mathrm{f}$ " allele) an associated decrease in the total MMSE score occurred. Furthermore, their results indicated that participants with the AA genotype (also referred to as "ff" genotype) had a faster decline in cognitive function than participants with other VDRFokI genotypes. No significant association was found between any other VDR polymorphism and PD in this study based on a level of significance of $p<0.05 .39$

Another study involving elderly subjects found significant associations between VDR-BsmI, VDR-TaqI and a low composite cognitive score (calculated by averaging the scores of other cognitive 
function tests) but not with a low MMSE score. ${ }^{40}$ Additionally, a significant association was observed between VDR-ApaI and less depressive symptoms based on the Geriatric Depression Scale. ${ }^{40}$

Since vitamin D was the nutrient of particular interest, blood $25(\mathrm{OH}) \mathrm{D}_{3}$ measurements would have provided further details surrounding the vitamin $\mathrm{D}$ status of participants. This is therefore a limitation in the present study.

\section{Future research directions}

Further research is necessary to either confirm or refute the presently observed associations of VDR gene variants with cognitive decline as measured using the MMSE scale. By obtaining a more thorough understanding of VDR variants and their influence on risk of cognitive decline, new insights into the underlying pathophysiology of cognitive decline and development of possible intervention and treatment strategies will emerge. These may include the screening of particular VDR polymorphisms as part of a routine health check and the use of supplemental vitamin D at a younger age. Based on the preliminary results of this study, we hypothesize that the use of vitamin $\mathrm{D}$ as a potential preventative agent in cognitive decline will reduce the impact this degenerative disorder currently has on our health system.

\section{Conclusions}

Our results show that the VDR-BsmI and VDR-TaqI polymorphisms are associated with cognitive decline in an elderly population. Since the elderly are particularly at risk for a number of degenerative disorders related to low serum $25(\mathrm{OH}) \mathrm{D}_{3}$ levels, including cognitive decline, further exploration of the influence of VDR gene variants is necessary to reveal the full extent of potential interactions.

\section{Acknowledgments}

Part of the research on which this paper is based was conducted as part of the Retirement Health and Lifestyle Study, The University of Newcastle. We are grateful to the Australian Research Council, Central Coast Local Health District Public Health Unit, UnitingCare Ageing NSW/ACT, Urbis Pty Ltd, Valhalla Village Pty Ltd, and Hunter Valley Research Foundation for funding the initial study and to the men and women of the Central Coast region who provided the information recorded. The authors would also like to thank the researchers and RHLS clinic staff based at Gosford Teaching Unit, including Jenny Marriott, Marie Mazaroli, Elizabeth Death, Jodi Humphreys, and Louise Lambeth. This research was supported by an Australian Research Council linkage grant (G0188386) awarded to Martin Veysey (lead CI).

\section{Conflict of interest}

The authors have no conflict of interests related to this publication.

\section{Author contributions}

Study design (CM, ML), performance of experiments (CM), anal- ysis and interpretation of data (CM, ML), manuscript writing (CM, $\mathrm{ZY}, \mathrm{MV})$, critical revision of the manuscript (CM, ZY, KK, SN, $\mathrm{ML})$, statistical analysis (CM), providing critical funding (MV).

\section{References}

[1] Annweiler C, Schott AM, Berrut G, Chauvire V, Le Gall D, Inzitari M, et al. Vitamin $D$ and ageing: neurological issues. Neuropsychobiology 2010;62(3):139-150. doi:10.1159/000318570.

[2] Buell JS, Dawson-Hughes B. Vitamin D and neurocognitive dysfunction: preventing "D"ecline? Mol Aspects Med 2008;29(6):415-422. doi:10.1016/j.mam.2008.05.001.

[3] Brown J, Bianco JI, McGrath JJ, Eyles DW. 1,25-dihydroxyvitamin D3 induces nerve growth factor, promotes neurite outgrowth and inhibits mitosis in embryonic rat hippocampal neurons. Neurosci Lett 2003;343(2):139-143. doi:10.1016/\$0304-3940(03)00303-3.

[4] Garcion E, Wion-Barbot N, Montero-Menei CN, Berger F, Wion D. New clues about vitamin D functions in the nervous system. Trends Endocrinol Metab 2002;13(3):100-105. doi:10.1016/S10432760(01)00547-1.

[5] Kalueff AV, Tuohimaa P. Neurosteroid hormone vitamin D and its utility in clinical nutrition. Curr Opin Clin Nutr Metab Care 2007;10(1):1219. doi:10.1097/MCO.0b013e328010ca18.

[6] Holmoy T, Moen SM. Assessing vitamin D in the central nervous system. Acta Neurol Scand 2010;122(Suppl 190):88-92. doi:10.1111/ j.1600-0404.2010.01383.x.

[7] Tuohimaa P, Keisala T, Minasyan A, Cachat J, Kalueff A. Vitamin D, nervous system and aging. Psychoneuroendocrinology 2009;34(Suppl 1):S278-S286. doi:10.1016/j.psyneuen.2009.07.003.

[8] Hossein-Nezhad A, Holick MF. Vitamin d for health: a global perspective. Mayo Clin Proc 2013;88(7):720-755. doi:10.1016/j.mayocp.2013.05.011.

[9] Hickson M. Malnutrition and ageing. Postgrad Med J 2006;82(963):28. doi:10.1136/pgmj.2005.037564.

[10] MacLaughlin J, Holick MF. Aging decreases the capacity of human skin to produce vitamin D3. J Clin Invest 1985;76(4):1536-1538. doi:10.1172/JCl112134.

[11] Llewellyn DJ, Lang IA, Langa KM, Muniz-Terrera G, Phillips CL, Cherubini $A$, et al. Vitamin $D$ and risk of cognitive decline in elderly persons. Arch Intern Med 2010;170(13):1135-1141. doi:10.1001/archinternmed.2010.173.

[12] Slinin Y, Paudel M, Taylor BC, Ishani A, Rossom R, Yaffe K, et al. Association between serum $25(\mathrm{OH})$ vitamin $D$ and the risk of cognitive decline in older women. J Gerontol A Biol Sci Med Sci 2012;67(10):10921098. doi:10.1093/gerona/gls075.

[13] van der Schaft J, Koek HL, Dijkstra E, Verhaar HJ, van der Schouw YT, Emmelot-Vonk MH. The association between vitamin D and cognition: a systematic review. Ageing Res Rev 2013;12(4):1013-1023. doi:10.1016/j.arr.2013.05.004.

[14] Imai CM, Halldorsson TI, Eiriksdottir G, Cotch MF, Steingrimsdottir L, Thorsdottir I, et al. Depression and serum 25-hydroxyvitamin D in older adults living at northern latitudes - AGES-Reykjavik Study. J Nutr Sci 2015;4:e37. doi:10.1017/jns.2015.27.

[15] Uitterlinden AG, Fang $Y$, Van Meurs JB, Pols HA, Van Leeuwen JP. Genetics and biology of vitamin D receptor polymorphisms. Gene 2004;338(2):143-156. doi:10.1016/j.gene.2004.05.014.

[16] Kostner K, Denzer N, Muller CS, Klein R, Tilgen W, Reichrath J. The relevance of vitamin D receptor (VDR) gene polymorphisms for cancer: a review of the literature. Anticancer Res 2009;29(9):3511-3536.

[17] Smolders J, Peelen E, Thewissen M, Menheere P, Tervaert JW, Hupperts $R$, et al. The relevance of vitamin $D$ receptor gene polymorphisms for vitamin $D$ research in multiple sclerosis. Autoimmun Rev 2009;8(7):621-626. doi:10.1016/j.autrev.2009.02.009.

[18] Ranganathan P. Genetics of bone loss in rheumatoid arthritis-role of vitamin $D$ receptor polymorphisms. Rheumatology (Oxford) 2009;48(4):342-346. doi:10.1093/rheumatology/ken473.

[19] Gong YL, Xie DW, Deng ZL, Bostick RM, Miao XJ, Zhang JH, et al. Vitamin D receptor gene Tru9l polymorphism and risk for incidental sporadic colorectal adenomas. World J Gastroenterol 2005;11(31):4794- 
4799. doi:10.3748/wjg.v11.i31.4794.

[20] Diorio C, Sinotte M, Brisson J, Berube S, Pollak M. Vitamin D pathway polymorphisms in relation to mammographic breast density. Cancer Epidemiol Biomarkers Prev 2008;17(9):2505-2508. doi:10.1158/1055-9965.EPI-08-0493.

[21] QIAGEN. QIAamp ${ }^{\circledR}$ DNA Mini Kit and QIAamp DNA Blood Mini Kit Handbook. 2001.

[22] Folstein MF, Folstein SE, McHugh PR. "Mini-mental state". A practical method for grading the cognitive state of patients for the clinician. J Psychiatr Res 1975;12(3):189-198. doi:10.1016/00223956(75)90026-6.

[23] Braekhus A, Laake K, Engedal K. A low, 'normal' score on the Mini-Mental State Examination predicts development of dementia after three years. J Am Geriatr Soc 1995;43(6):656-661. doi:10.1111/j.1532-5415.1995.tb07201.x.

[24] Sansone RA, Sansone LA. Sunshine, serotonin, and skin: a partial explanation for seasonal patterns in psychopathology? Innov Clin Neurosci 2013;10(7-8):20-24.

[25] Magnusson A. An overview of epidemiological studies on seasonal affective disorder. Acta Psychiatr Scand 2000;101(3):176-184. doi:10.1034/j.1600-0447.2000.101003176.x.

[26] Wilkins CH, Sheline YI, Roe CM, Birge SJ, Morris JC. Vitamin D deficiency is associated with low mood and worse cognitive performance in older adults. Am J Geriatr Psychiatry 2006;14(12):1032-1040. doi:10.1097/01.JGP.0000240986.74642.7c.

[27] Balion C, Griffith LE, Strifler L, Henderson M, Patterson C, Heckman $\mathrm{G}$, et al. Vitamin D, cognition, and dementia: a systematic review and meta-analysis. Neurology 2012;79(13):1397-1405. doi:10.1212/ WNL.0b013e31826c197f.

[28] Lehmann DJ, Refsum H, Warden DR, Medway C, Wilcock GK, Smith $A D$. The vitamin $D$ receptor gene is associated with Alzheimer's disease. Neurosci Lett 2011;504(2):79-82. doi:10.1016/j.neulet.2011.08.057.

[29] Gezen-Ak D, Dursun E, Bilgic B, Hanagasi H, Ertan T, Gurvit H, et al. Vitamin d receptor gene haplotype is associated with late-onset Alzheimer's disease. Tohoku J Exp Med 2012;228(3):189-196. doi:10.1620/ tjem.228.189.

[30] Beydoun MA, Ding EL, Beydoun HA, Tanaka T, Ferrucci L, Zonderman $A B$. Vitamin $D$ receptor and megalin gene polymorphisms and their associations with longitudinal cognitive change in US adults. Am J Clin Nutr 2012;95(1):163-178. doi:10.3945/ajcn.111.017137.

[31] Lee YH, Kim JH, Song GG. Vitamin D receptor polymorphisms and susceptibility to Parkinson's disease and Alzheimer's disease: a meta-analysis. Neurol Sci 2014;35(12):1947-1953. doi:10.1007/s10072014-1868-4.

[32] Keyimu K, Zhou XH, Miao HJ, Zou T. Relationship between vitamin D receptor gene polymorphism and mild cognitive impairment in elderly Uygur people. Int J Clin Exp Med 2014;7(12):5282-5288.

[33] Najmi Varzaneh F, Sharifi F, Hossein-Nezhad A, Mirarefin M, Maghbooli Z, Ghaderpanahi M, et al. Association of vitamin D receptor with longevity and healthy aging. Acta Med Iran 2013;51(4):236241.

[34] Gatto NM, Paul KC, Sinsheimer JS, Bronstein JM, Bordelon Y, Rausch R, et al. Vitamin $\mathrm{D}$ receptor gene polymorphisms and cognitive decline in Parkinson's disease. J Neurol Sci 2016;370:100-106. doi:10.1016/j. jns.2016.09.013.

[35] Kuningas M, Mooijaart SP, Jolles J, Slagboom PE, Westendorp RG, van Heemst D. VDR gene variants associate with cognitive function and depressive symptoms in old age. Neurobiol Aging 2009;30(3):466473. doi:10.1016/j.neurobiolaging.2007.07.001.

[36] Selvaraj P, Alagarasu K, Harishankar M, Vidyarani M, Narayanan PR. Regulatory region polymorphisms of vitamin $D$ receptor gene in pulmonary tuberculosis patients and normal healthy subjects of south India. Int J Immunogenet 2008;35(3):251-254. doi:10.1111/j.1744313X.2008.00764.x.

[37] Riggs BL, Nguyen TV, Melton LJ 3rd, Morrison NA, O'Fallon WM, Kelly $\mathrm{PJ}$, et al. The contribution of vitamin $\mathrm{D}$ receptor gene alleles to the determination of bone mineral density in normal and osteoporotic women. J Bone Miner Res 1995;10(6):991-996. doi:10.1002/ jbmr.5650100622.

[38] Falleti E, Bitetto D, Fabris C, Cussigh A, Fontanini E, Fornasiere E, et al. Vitamin $D$ receptor gene polymorphisms and hepatocellular carcinoma in alcoholic cirrhosis. World J Gastroenterol 2010;16(24):30163024. doi:10.3748/wjg.v16.i24.3016.

[39] Harris SS, Eccleshall TR, Gross C, Dawson-Hughes B, Feldman D. The vitamin $D$ receptor start codon polymorphism (Fokl) and bone mineral density in premenopausal American black and white women. J Bone Miner Res 1997;12(7):1043-1048. doi:10.1359/ jbmr.1997.12.7.1043.

[40] Halsall JA, Osborne JE, Epstein MP, Pringle JH, Hutchinson PE. The unfavorable effect of the $A$ allele of the vitamin $D$ receptor promoter polymorphism A-1012G has different mechanisms related to susceptibility and outcome of malignant melanoma. Dermatoendocrinol 2009;1(1):54-57. 